\title{
Biocontrol Activities of Gamma Induced Mutants of Trichoderma harzianum against some Soilborne Fungal Pathogens and their DNA Fingerprinting
}

\author{
Sakineh Abbasi 1, Naser Safaie *1, Masoud Shams-bakhsh 1, Samira Shahbazi ${ }^{*}$ \\ ${ }^{1}$ Department of Plant Pathology, Faculty of Agriculture, Tarbiat Modares University of Tehran, Tehran, Iran \\ ${ }^{2}$ Nuclear Science and Technology Research Institute, Atomic Energy Organization of Iran, Karaj, Iran \\ * Corresponding author: Naser Safaie, Department of Plant Pathology, Faculty of Agriculture, Tarbiat Modares University of Tehran, Iran. \\ Tel: +98-21-48292346, Fax: +98-21-48292200, E-mail: nsafaie@modares.ac.ir
}

Received: April 30, 2015; Revised: September 01, 2015; Accepted: May 31, 2016

Background: Random induced mutation by gamma radiation is one of the genetic manipulation strategies to improve the antagonistic ability of biocontrol agents.

Objectives: This study aimed to induce mutants with more sporulation, colonization rate leading to enhanced antagonistic ability (in vitro assay) comparing to wild type (WT) and the assessment of genetic differences (in situ evaluation) using molecular markers. The superior mutants could be appropriate biocontrol agents against soil borne fungal diseases.

Materials and Methods: In this research sampling and isolation of Trichoderma isolates were performed from soils with low incidence of soil borne disease. T. harzianum 65 was selected and irradiation was conducted with gammacell at optimal dose 250 Gray/s. Mutants (115) were obtained from the WT. The antagonistic abilities of twenty-four mutants were evaluated using dual culture and culture filtrate tests.

Results: The results of in vitro assays revealed that Th15, Th11 and Th1 mutants exhibited stronger growth inhibition (GI) and colonization rate on Macrophomina phaseolina and Rhizoctonia solani AG4 compared to the wild type. Th15 and Th11 mutants exhibited stronger GI and colonization rate on Sclerotinia sclerotiorum in dual culture and culture filtrate tests and Th1 and Th11 mutants exhibited stronger GI on Fusarium grminearum in culture filtrate test.

The DNA fingerprinting was carried out using RAPD and rep-PCR markers. Two (Th9 and Th17) out of the 24 mutants categorized distantly from the rest based on different polymorphism obtained by molecular markers. However, Th9 was different in GI\% from Th17. RAPD analysis separated WT from mutants, Th9 from Th17 and also phenotypically superior mutants from other mutants. Meanwhile, rep-PCR analysis categorized WT isolate and mutants according to their antagonistic properties.

Conclusions: The latter marker (rep-PCR) appeared to be reproducible and simple to distinguish mutants from a single isolate of $T$. harzianum. Mutants (3 isolates) were phenotypically and genotypically distinct from WT. These mutants demonstrated a pronounced biocontrol activities against soilborne fungal phytopathogens.

Keywords: Enhancement of antagonistic properties; Random Mutagenesis; RAPD and rep-PCR

\section{Background}

Advances in molecular aspects of antagonists have paved the way of creating improved biological control agents (iBCA). Induction of random mutations by physical mutagens such as $\mathrm{UV}, \mathrm{X}$, gamma radiation and chemical mutagens such as ethylmethane sulfonate have been used as useful tools to manipulate antagonists genetically $(1,2)$. Several studies have shown that gamma-ray radiation can cause genetic diversity of filamentous fungi and induce positive (3, 4 and 5) or negative mutants (6) of specific genes. Trichoderma species are filamentous fungi with teleomorphs belonging to the Hypocreales order of the Ascomycota. A number of potential biocontrol agents within the genus of Trichoderma have been reported that can act against soilborne plant pathogens, including T. harzianum (7). Several researchers have studied the enhancement of some metabolic functions such as 
secretion of extracellular cell wall-degrading enzymes and antibiotic production of mycoparasite Trichoderma isolates after a treatment by physical mutagens $(8,9,10,5$ and 11).

In situ identification of superior biocontrol isolate of Trichoderma was achieved by using Random Amplified Polymorphic DNA (RAPD) (12), Sequence Characterized Ampilfied Regions (SCAR) markers (13) and real-time PCR (14). Rep-PCR is the genomic fingerprinting method that is based on the use of DNA primers corresponding to naturally occurring interspersed repetitive elements in bacteria, such as the REP, ERIC and BOX elements and has been used to evaluate genetic diversity and distinguish strains in bacteria (15). This method has also been used for evaluation of genetic diversity of fungi including Fusarium oxysporum (16), Verticillium chlamydosporium (6) Leptosphaeria maculans (20), Macrophomina phaseolina (19), Rhizoctonia solani $(20,21)$ and Tilletia spp. (24); so far this method has not been applied for evaluation of genetic diversity in biocontrol isolates of Trichoderma species.

\section{Objectives}

Random gamma radiation with optimal dose (a dose at which near $50 \%$ of spores was abled to germinate) was applied on T. harzianum. Phenotypic alterations (antagonistic activities against some soil borne fungal pathogens) and genotype of gamma induced mutants were compared with WT via RAPD and rep$\operatorname{PCR}(23,24)$.

\section{Materials and Methods}

\subsection{Culture of Microorganisms}

T. harzianum was isolated from soil rhizosphere of healthy plants (Beta vulgaris) adjacent to or between two wilted plants in Khuzestan province, using dilution plate technique on Trichoderma selective medium (TSM) (25) and purified by single spore culture. The isolates were identified on the basis of their morphological characteristics (26). The purified and identified cultures of T. harzianum were maintained on Potato Dextrose Agar (PDA) medium and stored at $4{ }^{\circ} \mathrm{C}$ for further use. Soilborne fungal plant pathogens including F. graminearum (Fusarium head blight of wheat), $S$. sclerotiorum (Sclerotinia stem rot of canola), $M$. phaseolina (charcoal rot of melon) and $R$. solani AG4 (melon damping-off) were received from the Culture Collection of the Tarbiat Modares University.

\subsection{T. harzianum dose Assessmentand Mutants Isolation}

Spore suspension $\left(10^{7} \mathrm{~mL}^{-1}\right)$ of $T$. harzianum 65 (Th65) isolate (WT) was spread on Water-Agar (WA) plates then irradiated with gammacell (Co- 60 , activity 2500 Curry, rate dose of 0.23 Gy.second ${ }^{-1}$ by doses of $0,50,150,200,250,300,350,400$ and 450 Gy at Nuclear Science and Technology Research Institute of Iran and incubated at $25^{\circ} \mathrm{C}$ for 7 days. The irradiated spores of each dose were transformed to PDA plates by a needle. After $24 \mathrm{~h}$, percentage of germinated spores was recorded (24).

\subsection{Antagonistic Activity Assay Against 4 Soilborne Phytopathogens}

Mutants (24) selected and Th65 (WT) were evaluated in vitro against four soil borne phytopathogens into dual culture described by Dennis and Webster (27). Culture filtrates (extracellular extract or nonvolatile compounds) were tested according to Dennis and Webster (28). The mutants and Th65 (WT) were inoculated in conical flasks $(250 \mathrm{~mL})$ containing 100 $\mathrm{mL}$ potato dextrose broth. Inoculated flasks were incubated at $23 \pm 1^{\circ} \mathrm{C}$ at $70 \mathrm{rpm}$ for 12 days. The culture was filtered through Micropore filter $\left(0.22 \mu \mathrm{m}\right.$, Syringe $\left.{ }^{\circledR}\right)$ and culture filtrate was added to PDA at $42^{\circ} \mathrm{C}$ to obtain a final concentration of $10 \%(\mathrm{v} / \mathrm{v})$. The medium was poured into the $9 \mathrm{~cm}$ plates with $15 \mathrm{~mL}$.plate ${ }^{-1}$. The medium was inoculated with $7 \mathrm{~mm}$ discs of above mentioned pathogens and control plates with no inoculation. The plates were sealed with Parafilm tape and incubated at $27 \pm 1^{\circ} \mathrm{C}$, except for $S$. sclerotiorum that incubated at $23^{\circ} \mathrm{C}$ for three days (Figure 1). Pathogens' GI\% were calculated as GI\% $=(\mathrm{dc}$ $\mathrm{dt}) / \mathrm{dc} \times 100$, where $\mathrm{dc}$ is colony diameter of pathogen in control, and dt is colony diameter of pathogen in treatment. The experiments were conducted in completely randomized design with three replicates and analyzed by SAS (version 9.1). The means were compared with Duncan's Multiple Range Test $(\mathrm{P}<0.05)$.

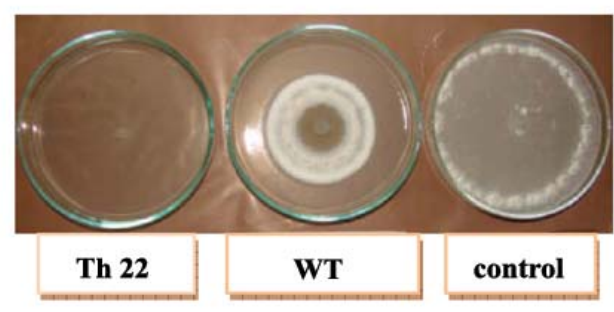

Figure 1. The effect of culture filtrate of Th22 mutant inoculated with $S$. sclerotiorum in comparition with culture filtrate of Th65 (WT) and control (without culture filtrate) after 7 days incubation at $23 \pm 1^{\circ} \mathrm{C}$ 
Table 1. The RAPD and rep-PCR primers used

\begin{tabular}{lc}
\hline Primers & Sequence \\
\hline OPA-10 & GTGATCGCAG \\
OPA-11 & CAATCGCCGT \\
OPA-14 & TCTGTGCTGG \\
OPA-18 & AGGTGACCGT \\
OPA-16 & AGCCAGCGAA \\
rep 1R-I & IIICGICGICATCIGGC- \\
rep 2-I & IIICGNCGNCATCNGGC \\
Eric 1R & ATGTAAGCTCCTGGGGATCAC \\
Eric2 & AAGTAAGTGACTGGGGTGAGCG \\
Box A1R & CTACGGCAAGGCGACGCTGACG \\
\hline
\end{tabular}

\subsection{Biomass Production and DNA Extraction}

From edges of a 3-day old fungal culture, 3-4 pieces were transferred to flat bottles with $50 \mathrm{~mL}$ of Potato Dextrose Broth (PDB) and placed at $25^{\circ} \mathrm{C}$ for $48 \mathrm{~h}$ at $125 \mathrm{rpm}$. Mycelia were harvested on filter paper (Whatman No.1) by vacuum pump and stored at $-70^{\circ} \mathrm{C}$ for further use. DNA extraction was performed as previously described by Safaie et al. (29). Quality and quantity of extracted DNA were assessed by electrophoresis on $0.8 \%$ agarose gel and biophotometer (Eppendorf, Germany), respectively.

\subsection{Randomly Amplified Polymorphic DNA (RAPD) Analysis}

The polymerase chain reactions (PCRs) were carried out in $20 \mu \mathrm{L}$ of master mix containing $20 \mathrm{ng}$ of genomic DNA template and 10 pmols of random primer (Table 1) (Sinaclon, Iran). All PCR reactions were started at $92^{\circ} \mathrm{C}$ for 3 min and 30 cycles of $92^{\circ} \mathrm{C}: 1$ min; $33^{\circ} \mathrm{C}$ : (except for $35^{\circ} \mathrm{C}$ for OPA09) $1 \mathrm{~min}$; and $72^{\circ} \mathrm{C}: 2 \mathrm{~min}$. The cycles were followed by single cycle of $5 \mathrm{~min}$ at $72^{\circ} \mathrm{C}$ in an epgradient thermocycler (Eppendorf, Germany). Each reaction of RAPD-PCR repeated twice.

\subsection{Repetitive Sequence-based PCR (rep-PCR) Analysis}

PCR reaction was carried out in $20 \mu \mathrm{L}$ and in an epgradient thermocycler (Eppendorf, Germany). The master mix included: $2 \mu \mathrm{L}$ of buffer $(10 \times$ PCR buffer) $0.5 \mu \mathrm{L} \mathrm{Taq}$ Polymerase (5 unit. $\left.\mu \mathrm{L}^{-1}\right), 0.8 \mu \mathrm{L}(0.5 \mathrm{mM})$ $\mathrm{MgCl}_{2}, 0.4 \mu \mathrm{L}$ mixture of nucleotides $(10 \mathrm{mM}), 1 \mu \mathrm{L}$ $(10 \mathrm{pM})$ of each primer (Table 1) and $1 \mu \mathrm{L}(20 \mathrm{ng})$ template DNA. In negative control $1 \mu \mathrm{L}$ of sterile deionized water was added instead of DNA. Thermal cycles were set up with some modifications as described by McDonald et al. (22). For rep-PCR initial at the PCR was initiated at $94^{\circ} \mathrm{C}$ for $7 \mathrm{~min}$, followed by 35 (for rep 1R-I) and 40 (for rep 2I) cycles of $92^{\circ} \mathrm{C}: 1$ $\min ; 43^{\circ} \mathrm{C}$ (for rep 1R-I) and 40 (for rep $2 \mathrm{I}$ ): $1 \mathrm{~min}$; $72^{\circ} \mathrm{C}$ : $2 \mathrm{~min}$. Final extension was $10 \mathrm{~min}$ at $72^{\circ} \mathrm{C}$. For BOX-PCR initial denaturation was $94^{\circ} \mathrm{C}$ for 3 min that followed by 30 cycles of $94^{\circ} \mathrm{C}$ : $1 \mathrm{~min} ; 53^{\circ} \mathrm{C}$ : $1 \mathrm{~min}$; $65^{\circ} \mathrm{C}$ : $2 \mathrm{~min}$. These cycles were followed by single cycle at $65^{\circ} \mathrm{C}$ for $8 \mathrm{~min}$. For ERIC-PCR initial denaturation was at $95^{\circ} \mathrm{C}$ for 2 min and 35 cycles of $\left[94^{\circ} \mathrm{C}: 1\right.$ $\left.\min ; 51^{\circ} \mathrm{C}: 1 \mathrm{~min} ; 72^{\circ} \mathrm{C}: 2 \mathrm{~min}\right]$. These cycles were followed by single cycle at $72^{\circ} \mathrm{C}$ for $7 \mathrm{~min}$. The PCR products and $1 \mathrm{~kb}$ ladder were separated on $1.4 \%(\mathrm{w} / \mathrm{v})$ agarose gel. The bands were visualized by staining with ethidium bromide ( $\left.1 \mathrm{mg} \cdot \mathrm{mL}^{-1}\right)$ on UV transluminator and data were analyzed using the MVSP software (with Jaccard coefficient).

\section{Results}

\subsection{Mutagenesis and Isolation of T. harzianum 65 Mutants}

Dose of $450 \mathrm{~Gy}$ completely (100\%) inhibited spore germination. At $250 \mathrm{~Gy}, 40-50 \%(43.4 \%)$ of spores germinated and therefore was selected as the optimum dose for irradiation (data obtained for the other doses not shown). Mutants (115) were obtained from WT (Th65) and were all tested for growth inhibition against $R$. solani (data not shown). Accordingly, 24 mutants were selected. The gamma radiation caused differences in morphological properties of $T$. harzianum such as color, colony appearance, sporulation and growth rate of mycelia at different irradiation. Th1, Th5, Th6 and Th8 mutants had more sporulation in comparison to WT and Th17 showed less after five days of incubation (data not shown).

\subsection{In vitro Assays}

The GI\% of $S$. sclerotiorum, F. graminearum, $M$. phaseolina and $R$. solani AG4 after 3 days of incubation with culture filtrate in dual culture (Tables 2-5) revealed significant differences among mutants and WT $(\mathrm{p}<0.05)$. In between, Th15 showed maximum GI\%. Other superior mutants were Th11, Th1 and Th22. Assay of antagonistic activity against $F$. graminearum revealed that Th11, Th22, Th2, Th15 and Th17 caused more GI\% than WT (Table 2). Antagonistic assay against $R$. solani revealed that Th17, Th9, Th11, Th1 and Th21 resulted in more GI\% than WT (Table 3). In vitro assay against $S$. sclerotiorum revealed that Th5, Th4, Th11 and Th22 had more GI\% than WT (Table 4). In vitro assay against $M$. phaseolina revealed that Th1, Th11, Th15 and Th18 had maximum GI\% (Table 5). The maximum GI\% by mutant culture filtrates were 
Table 2. The means of GI\% of $F$. graminearum exposed to mutants of $T$. harzianum (Th1- Th24) and WT (Th65) after 3 days incubation in dual culture $(\mathrm{A})$ and culture filtrate $(\mathrm{B})$ using Duncan's Test $(\mathrm{P}<0.05)$. Means followed by the same letters indicate no significant difference. Variance analysis of dual culture test and culture filtrate test are shown below respectively

\begin{tabular}{|c|c|c|c|c|c|}
\hline Mutants & Means (A) & Duncan Grouping & Mutants & Means (B) & Duncan Grouping \\
\hline Th21 & 60.70 & $A$ & Th11 & 50.00 & $A$ \\
\hline Th17 & 60.20 & $A$ & Th18 & 47.50 & $A B$ \\
\hline Th5 & 60.20 & $A$ & Th1 & 47.50 & $A B$ \\
\hline Th9 & 59.20 & $A$ & Th3 & 44.16 & $\mathrm{ABC}$ \\
\hline Th4 & 58.70 & A & Th9 & 40.00 & $A B C$ \\
\hline Th65 (WT) & 57.20 & $A B$ & Th24 & 36.66 & $B C D$ \\
\hline Th23 & 56.20 & $A B C$ & Th19 & 33.33 & CDE \\
\hline Th7 & 53.70 & $B C D$ & Th16 & 32.50 & CDEF \\
\hline Th16 & 52.20 & $\mathrm{DC}$ & Th12 & 26.66 & DEFG \\
\hline Th12 & 52.20 & $\mathrm{DC}$ & Th13 & 22.50 & $\mathrm{EFGH}$ \\
\hline Th20 & 52.20 & $\mathrm{DC}$ & Th10 & 21.66 & EFGHI \\
\hline Th14 & 51.73 & $\mathrm{DC}$ & Th21 & 20.00 & FGHI \\
\hline Th15 & 51.73 & $\mathrm{DC}$ & Th65(WT) & 18.33 & GHIJ \\
\hline Th8 & 51.70 & $\mathrm{DC}$ & Th22 & 17.50 & GHIJ \\
\hline Th22 & 51.23 & $\mathrm{DC}$ & Th7 & 17.50 & GHIJ \\
\hline Th19 & 51.23 & $\mathrm{DC}$ & Th15 & 15.83 & GHIJK \\
\hline Th18 & 50.73 & $D$ & Th4 & 12.50 & HIJKL \\
\hline Th2 & 50.23 & $D$ & Th2 & 10.83 & HIJKL \\
\hline Th11 & 50.23 & D & Th6 & 10.00 & HIJKL \\
\hline Th24 & 49.73 & $\mathrm{D}$ & Th23 & 9.16 & HIJKL \\
\hline Th13 & 49.23 & $D$ & Th8 & 8.33 & IJKL \\
\hline Th10 & 49.23 & $\mathrm{D}$ & Th17 & 8.33 & IJKL \\
\hline Th3 & 48.76 & $D$ & Th14 & 5.00 & $\mathrm{JKL}$ \\
\hline Th1 & 48.76 & D & Th20 & 3.33 & $\mathrm{KL}$ \\
\hline Th6 & 42.80 & $E$ & Th5 & 0.00 & $\mathrm{~L}$ \\
\hline
\end{tabular}

Table 3. The means of GI\% of R. solani exposed to mutants of T. harzianum (Th1-Th24) and WT (Th65) after 3 days incubation in dual culture (A) and culture filtrate $(\mathrm{B})$ using Duncan's Test $(\mathrm{P}<0.05)$. Means followed by the same letters indicate no significant difference. Variance analysis of dual culture test and culture filtrate test are shown below respectively

\begin{tabular}{|c|c|c|c|c|c|}
\hline Mutants & Means (A) & Duncan Grouping & Mutants & Means (B) & Duncan Grouping \\
\hline Th11 & 48.73 & $A$ & Th22 & 44.43 & $A$ \\
\hline Th17 & 48.73 & $A$ & Th2 & 43.06 & $A$ \\
\hline Th4 & 48.70 & $A$ & Th15 & 43.03 & $A$ \\
\hline Th12 & 48.70 & $A$ & Th7 & 41.70 & $A$ \\
\hline Th9 & 47.86 & $A B$ & Th13 & 40.26 & $A$ \\
\hline Th7 & 47.86 & $A B$ & Th8 & 33.33 & $A B$ \\
\hline Th2 & 47.00 & $A B$ & Th3 & 26.36 & $\mathrm{BC}$ \\
\hline Th22 & 47.00 & $A B$ & Th11 & 20.86 & $B C D$ \\
\hline Th19 & 47.00 & $A B$ & Th21 & 16.70 & CDE \\
\hline Th20 & 47.00 & $A B$ & Th19 & 16.70 & $\mathrm{CDE}$ \\
\hline Th10 & 46.16 & $A B$ & Th4 & 16.66 & CDE \\
\hline Th21 & 45.33 & $A B$ & Th10 & 16.66 & CDE \\
\hline Th18 & 45.33 & $A B$ & Th12 & 15.26 & CDEF \\
\hline Th13 & 44.46 & $A B$ & Th14 & 15.26 & CDEF \\
\hline Th15 & 44.46 & $A B$ & Th9 & 12.20 & CDEFG \\
\hline Th6 & 44.46 & $A B$ & Th1 & 11.50 & DEFG \\
\hline Th14 & 44.43 & $A B$ & Th18 & 11.40 & DEFG \\
\hline Th23 & 43.63 & $A B$ & Th20 & 10.88 & DEFG \\
\hline Th3 & 43.60 & $A B$ & Th16 & 9.20 & DEFG \\
\hline Th24 & 43.60 & $A B$ & Th65(WT) & 5.20 & EFG \\
\hline Th16 & 43.60 & $A B$ & Th23 & 3.90 & EFG \\
\hline Th1 & 42.76 & $A B C$ & Th6 & 2.60 & $\mathrm{FG}$ \\
\hline Th8 & 42.73 & $A B C$ & Th24 & 2.00 & FG \\
\hline Th5 & 41.86 & $\mathrm{BC}$ & Th5 & 1.70 & FG \\
\hline Th65(WT) & 36.76 & C & Th17 & 0.20 & $\mathrm{G}$ \\
\hline
\end{tabular}


$\mathbf{A}$

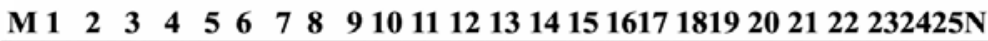

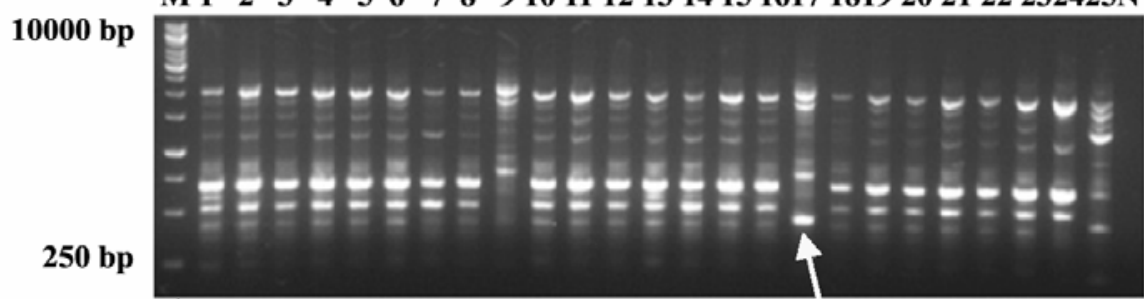

B

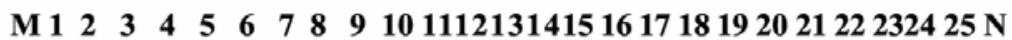

10000 bp

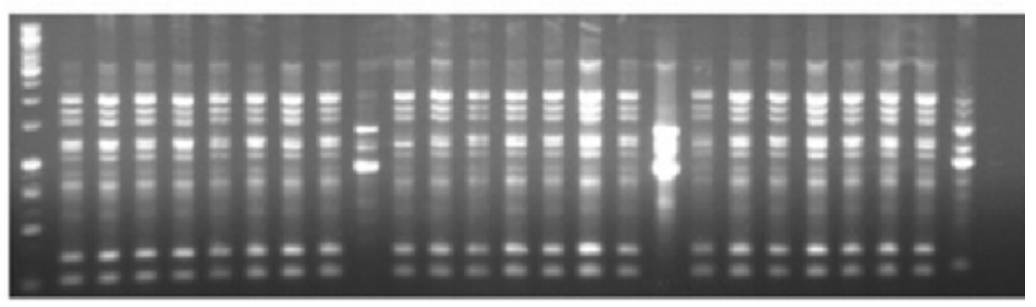

Figure 2. DNA fingerprinting of Trichoderma harzianum by A: OPA010 and B: OPA016; wells 1 to 24 are mutants (Th1-Th24) and 25 is WT. OPA010 amplified a 500 bp band, which separated Th17 from Th9, other mutants and WT, N: negative control and M: $1 \mathrm{kbp}$ DNA ladder

recorded in S. sclerotiorum (Table 4). In dual culture test, Th4, Th5, Th9, Th11, Th15 and Th17 demonstrated maximum GI\% against studied pathogens. Th1, Th4, Th9, Th11, Th15 and Th18 showed more colonization rate than WT after 3 days of incubation with mentioned phytopathogens (data not shown). Culture filtrate tests of Th1, Th2, Th11, Th15 and Th22 showed maximum GI\% against studied pathogens (Figures 2 to 5).

\subsection{RAPD Analysis}

Cluster analysis of RAPD amplicons using 5 random primers revealed a significant genetic diversity between the mutants and WT. OPA010, OPA011, OPA016, OPA09 and OPA014 were managed to amplify 19, 22, 22, 21 and 21 loci, respectively. The percentage of polymorphic bands detected with these primers, were $57.8,50,50,61.9$ and $47.6 \%$, respec-

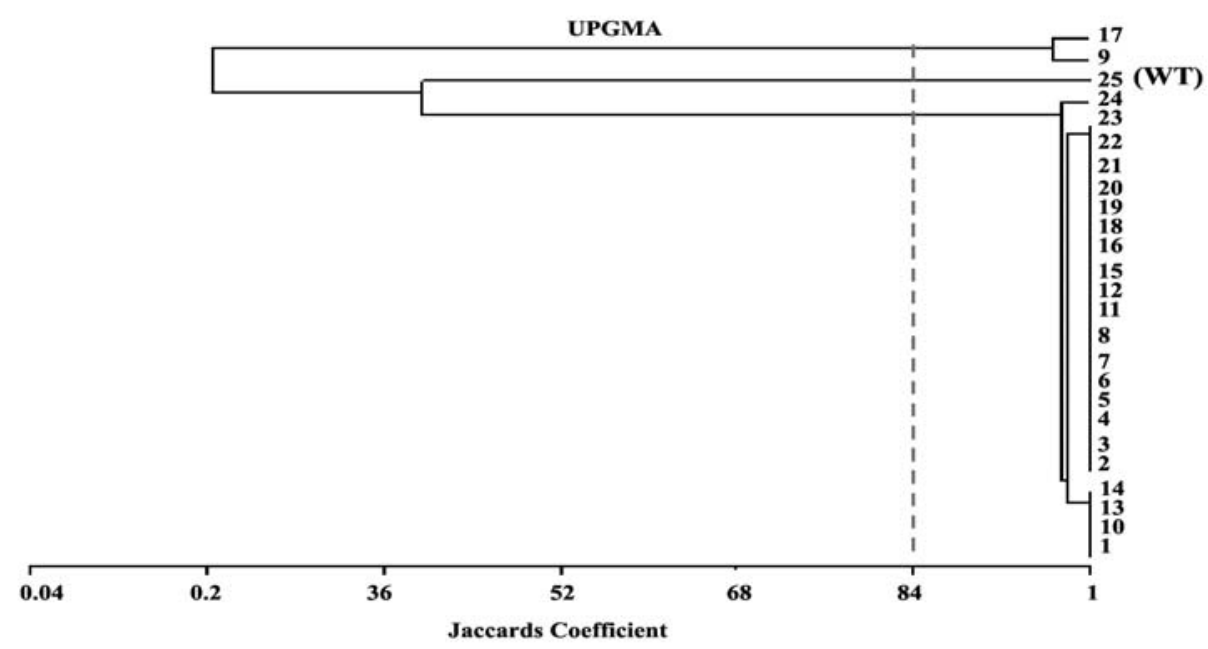

Figure 3. Dendrogram constructed with UPGMA clustering method using the MVSP software for the mutants and wild type of T. harzianum derived from pooled RAPD data 
Table 4. The means of GI\% of S. sclerotiorum exposed to mutants of T. harzianum (Th1- Th24) and WT (Th65) after 3 days incubation in dual culture $(\mathrm{A})$ and culture filtrate $(\mathrm{B})$ using Duncan's Test $(\mathrm{P}<0.05)$. Means followed by the same letters indicate no significant difference. Variance analysis of dual culture test and culture filtrate test are shown below respectively

\begin{tabular}{|c|c|c|c|c|c|}
\hline Mutants & Means (A) & Duncan Grouping & Mutants & Means (B) & Duncan Grouping \\
\hline Th5 & 88.40 & $A$ & Th4 & 100.00 & $A$ \\
\hline Th11 & 88.40 & A & Th22 & 99.26 & $A$ \\
\hline Th16 & 84.50 & $A B$ & Th23 & 98.53 & $A$ \\
\hline Th24 & 76.70 & $A B C$ & Th2 & 98.53 & A \\
\hline Th15 & 76.70 & $A B C$ & Th12 & 98.53 & $A$ \\
\hline Th17 & 75.26 & $A B C$ & Th8 & 97.80 & $A$ \\
\hline Th6 & 72.83 & $A B C D$ & Th10 & 96.86 & $A$ \\
\hline Th10 & 69.76 & ABCDE & Th7 & 94.10 & $A B$ \\
\hline Th9 & 68.96 & ABCDE & Th6 & 94.10 & $A B$ \\
\hline Th12 & 68.96 & ABCDE & Th14 & 93.30 & $A B$ \\
\hline Th19 & 68.96 & $A B C D E$ & Th11 & 91.83 & $A B C$ \\
\hline Th22 & 67.43 & $A B C D E$ & Th5 & 91.10 & $A B C$ \\
\hline Th21 & 67.43 & ABCDE & Th20 & 91.10 & $A B C$ \\
\hline Th8 & 65.10 & BCDEF & Th3 & 88.13 & $A B C D$ \\
\hline Th18 & 65.10 & BCDEF & Th9 & 86.66 & $A B C D$ \\
\hline Th7 & 63.56 & BCDEF & Th21 & 86.66 & $A B C D$ \\
\hline Th3 & 57.36 & CDEF & Th15 & 85.40 & $A B C D$ \\
\hline Th20 & 55.83 & CDEF & Th19 & 82.96 & $A B C D$ \\
\hline Th13 & 53.46 & DEF & Th16 & 77.76 & BCDE \\
\hline Th2 & 49.63 & $\mathrm{EF}$ & Th65(WT) & 74.83 & CED \\
\hline Th4 & 49.63 & $\mathrm{EF}$ & Th1 & 73.33 & $\mathrm{DE}$ \\
\hline Th23 & 45.76 & $\mathrm{~F}$ & Th24 & 73.30 & $\mathrm{DE}$ \\
\hline Th65(WT) & 44.96 & $\mathrm{~F}$ & Th18 & 65.90 & $\mathrm{EF}$ \\
\hline Th1 & 14.73 & $\mathrm{G}$ & Th13 & 55.53 & $\mathrm{~F}$ \\
\hline Th14 & 9.33 & $\mathrm{G}$ & Th17 & 23.00 & G \\
\hline
\end{tabular}

Table 5. The means of GI\% of M. phaseolina exposed to mutants of T. harzianum (Th1- Th24) and WT (Th65) after 3 days incubation in dual culture (A) and culture filtrate (B) using Duncan's Test $(\mathrm{P}<0.05)$. Means followed by the same letters indicate no significant difference. Variance analysis of dual culture test and culture filtrate test are shown below respectively

\begin{tabular}{|c|c|c|c|c|c|}
\hline Mutants & Means (A) & Duncan Grouping & Mutants & Means (B) & Duncan Grouping \\
\hline Th15 & 61.43 & $A$ & Th1 & 69.03 & $A$ \\
\hline Th12 & 59.96 & $A B$ & Th11 & 61.90 & $A B$ \\
\hline Th1 & 59.50 & $A B C$ & Th15 & 59.93 & $A B$ \\
\hline Th18 & 59.50 & $A B C$ & Th21 & 58.70 & $A B C$ \\
\hline Th14 & 59.50 & $A B C$ & Th24 & 56.36 & $A B C$ \\
\hline Th10 & 59.50 & $A B C$ & Th18 & 55.56 & $A B C$ \\
\hline Th11 & 57.60 & $A B C D$ & Th3 & 52.36 & $A B C$ \\
\hline Th17 & 55.93 & BCDE & Th16 & 49.23 & $B C D$ \\
\hline Th7 & 55.23 & CDEF & Th22 & 49.20 & $B C D$ \\
\hline Th13 & 54.76 & DEFG & Th2 & 47.63 & BCDE \\
\hline Th20 & 54.30 & DEFGH & Th17 & 45.23 & BCDEF \\
\hline Th24 & 53.83 & DEFGHI & Th9 & 45.23 & BCDEF \\
\hline Th23 & 53.80 & DEFGHI & Th19 & 40.46 & CDEFG \\
\hline Th19 & 53.33 & DEFGHI & Th10 & 32.56 & DEFG \\
\hline Th5 & 52.86 & EFGHI & Th65(WT) & 32.53 & DEFG \\
\hline Th3 & 51.90 & EFGHI & Th13 & 30.96 & DEFGH \\
\hline Th16 & 50.96 & FHGI & Th12 & 29.4 & EFGH \\
\hline Th65(WT) & 50.46 & $\mathrm{HGI}$ & Th23 & 28.6 & $\mathrm{GHF}$ \\
\hline Th9 & 50.00 & $\mathrm{HI}$ & Th4 & 25.4 & $\mathrm{GHI}$ \\
\hline Th8 & 49.53 & I & Th8 & 24.6 & $\mathrm{GHI}$ \\
\hline Th6 & 40.50 & $J$ & Th7 & 23.00 & $\mathrm{GHI}$ \\
\hline Th2 & 40.50 & $\mathrm{~J}$ & Th14 & 13.50 & $\mathrm{HI}$ \\
\hline Th21 & 40.50 & $\mathrm{~J}$ & Th5 & 12.70 & $\mathrm{HI}$ \\
\hline Th4 & 38.10 & KJ & Th20 & 10.33 & 1 \\
\hline Th22 & 35.70 & $\mathrm{~K}$ & Th6 & 8.70 & I \\
\hline
\end{tabular}


$\mathbf{A}$

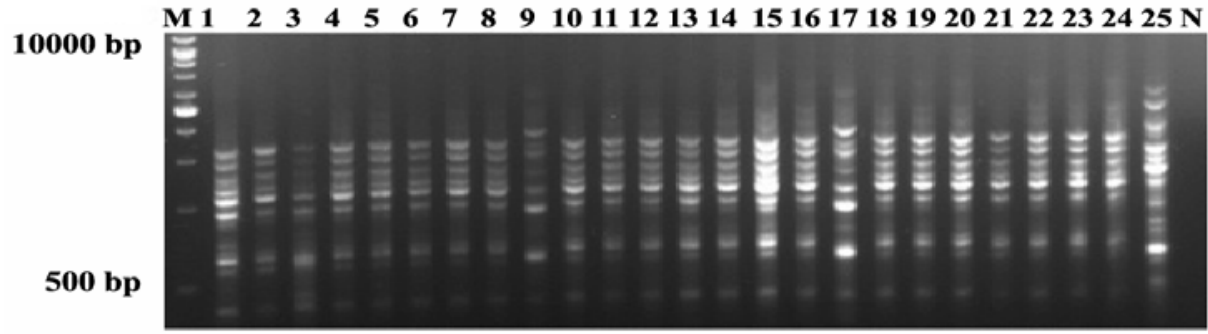

B

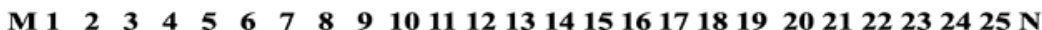

10000 bp

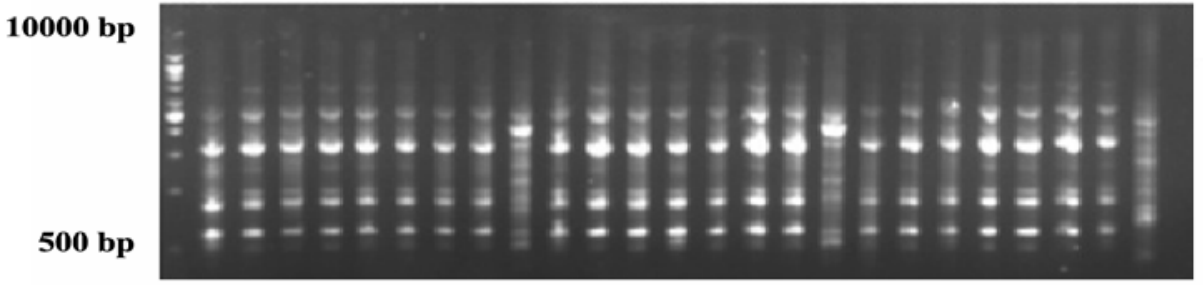

Figure 4. DNA fingerprinting of Trichoderma harzianum by A: rep1R-I and B: ERIC1; wells 1 to 24 are mutants (Th1-Th24) and 25 is WT, N: negative control and M: 1 kbp DNA ladder

tively. The most amplified loci belonged to OPA011 and OPA016 (Figure 2). DNA fingerprinting using RAPD-PCR revealed that gamma radiation induced genetic changes (Figure 2). The result obtained for combination of five primers of RAPD at similarity level of $84 \%$ divided the mutants and WT into 3 groups where the wild type and the Th9 and Th17 mutants were grouped in two separate clades and the rest of mutants in a group in close distance to mutants (Figure 3).

\subsection{Rep-PCR Analysis}

rep-PCR primers (5) with a similarity of $84 \%$ divided the mutants and WT into 3 groups: the group of WT, Th9 and Th17 in a group and the other mutants in other group. The mutants with improved antagonistic activity, Th9 and Th17, separated from WT, in a distinct group (Figure 5). The results obtained for cluster analysis of 5 primers of rep-PCR and DNA fingerprinting revealed that gamma mutation induced genetic changes (Figure 4). Number of identified loci included

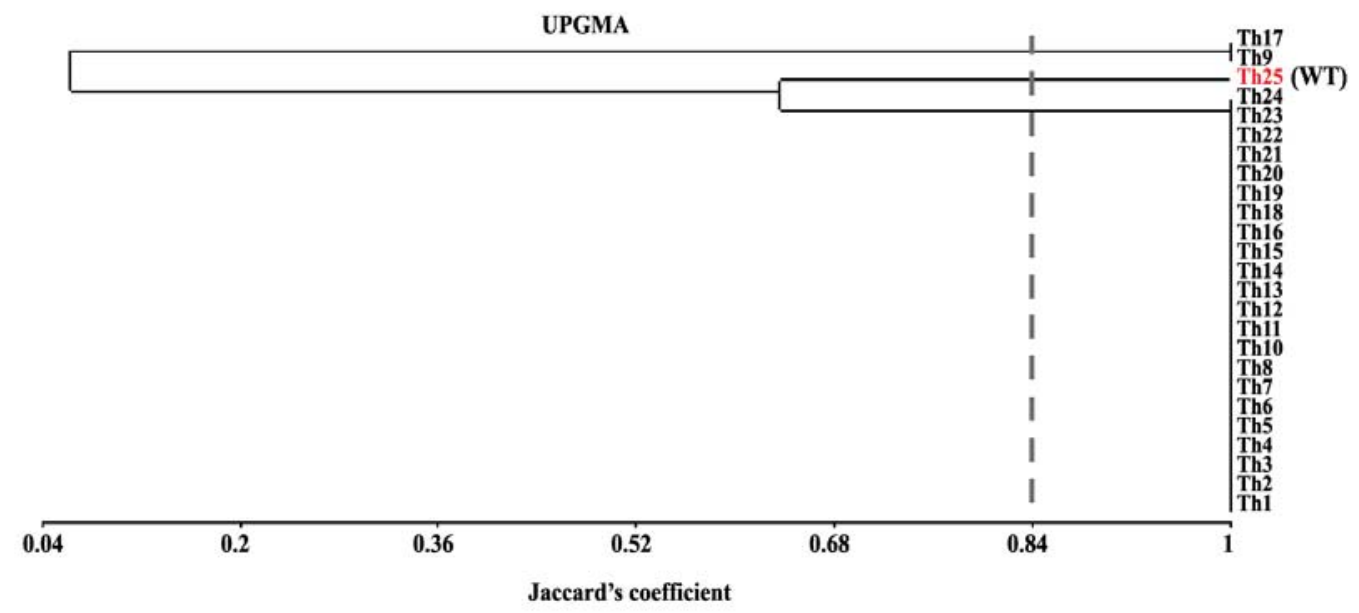

Figure 5. Dendrogram constructed with UPGMA clustering method using the MVSP software for the mutants and wild type of T. harzianum derived from pooled REP data 
for REP1R-I, REP2I, Box, ERIC2I and ERIC1 were $26,23,15,21$ and 21 , respectively and the percentage of polymorphic bands detected in these primers were $73.70,56.5,53.3,61.9$ and $66.6 \%$. rep1R-I produced the highest number of loci (Figure 4A). Rep-PCR revealed more polymorphic bands than RAPD-PCR.

\section{Discussion}

Gamma rays have very high energy, causing gene mutations by replacement of nucleotides (by oxidative deamination) or chromosome breakage. Here, random mutation by gamma irradiation with optimal dose of 250 Gy on T. harzianum caused changes in the genome and induced some mutants with more growth and sporulation rates than WT, with improved antagonistic activity for some such as Th1 mutant. Th15, Th11 and Th1 exhibited greater GI\% and colonization rate on $F$. graminearum, S. sclerotiorum, M. phaseolina and $R$. solani AG4 compared to WT. The obtained data on dual culture tests of isolates like that of culture filtrate assays indicated gamma radiation significantly affected production of extracellular compounds and enzymes involved in mycoparasitism. These secreted molecules led to high antagonistic activities against pathogens in some mutants; some of which showed good performance in dual culture test. However, some others such as Th5 demonstrated weak secretion of enzymes in culture filtrate test. Phenotypically, some other mutants demonstrated improved extracellular secretion, while their colonizations in dual culture were slow.

Induction of mutation is a genetic manipulation method to improve efficacy of biocontrol agents against soil borne plant pathogens (30). Szekeres et al. (31) reported that $T$. harzianum treated with UV overproduced protease, leading to much biocontrol activity against soil borne fungal phytopathogens. Similarly, Vaidya et al. (32) UV radiated Alcaligenes xylosoxydans produced more chitinase with enhanced biocontrol activity against soil borne fungal pathogens.

The DNA fingerprinting managed to distinguish between mutants and WT with well-coherency with their antagonistic capabilities similar to earlier works $(33,34,35$ and 36$)$.

Among the RAPD primers used, OPA010 amplified a reproducible $500 \mathrm{bp}$ band that separated Th17 from Th9 and other mutants and WT (Figure 2A). According to in vitro assays (Tables 2-5) GIs\% of Th9 and Th17 in dual culture tests were similar, but $T h 9$ showed more colonization and growth rate than Th17. Furthermore, in culture filtrate assays Th9 showed higher GI\% than Th17, probably this band is related to gene(s) that affects expression of special mycoparasitic enzymes that needs further analysis. Dendrogram of cluster analysis of RAPD (OPA010) separated Th9 from Th17 with $96 \%$ coefficient (Figure 3). Zymand et al. (37) used RAPD and identified T-39 of $T$. harzianum. Dodd et al. (38) used SCAR to recognize GV4 from other $T$. virens isolates.

Rep-PCR fingerprinting was reproducible and easy to assay in T. harzianum. The rep1R-I produced more polymorphic bands and detected more loci than other primers in rep-PCR. Markers that were used here mangaed to differentiate WT and mutants and efficiently established these differences with the phenotype of antagonism against fungal phytopathogens. Trombert et al. (39) used rep-PCR to distinguish UV mutation in Escherichia coli and observed that it was a suitable marker to show the effects of UV mutation in microorganisms. Afsharmanesh et al. (40) assessed the random mutagenesis by gamma radiation on Bacillus subtilis UTB1 in biocontrolling Aspergillus flavus. Eight mutants out of the 45 were selected based on different polymorphicpatterns, obtained by rep-PCR (ERIC and BOX). Of which, six mutants showed enhanced production of biosurfactants and produced more robust biofilm than the wild type UTB1. Several studies have shown that gamma ray radiation could change the enzyme activity and other antifungal metabolites (41, 42). Ahari et al. (23) applied gamma irradiation 150 Gy.second ${ }^{-1}$ (by 0.38 rate dose) on $F$. solani f.sp. phaseoli and were able to induce production of nonpathogenic mutants as biocontrol agents against pathogenic isolates ( $F$. solani f.sp. phaseoli). Here, three mutants were introduced that cauld possibly be used as effective biocontrol agents against the mentioned soil borne fungal pathogens. Further studies on enzyme assays of superior mutants, sequencing of their differential bands obtained in other molecular marker analyses are needed to provide the mechanism involved in antagonistic activity of the mutants and finally to test the biocontrol abilities of mutants in nature.

\section{References}

1. Catlett N, Lee BN, Yoder OC, Turgeon BG. Split-marker recombination for efficient targeted deletion of fungal genes. Fung Genet Newsl. 2003;50:9-11.

2. Gohel V, Megha C, Vyas P, Chhatpar HS. Strain improvement of chitinolytic enzyme producing isolate Pantoea dispersa for enhancing its biocontrol potential against fungal plant pathogens. Ann Microbiol. 2004;54(4):503-515.

3. Abbasi S, Safaie N, Shamsbakhsh M. Evaluation of gammainduced mutants of Trichoderma harzianum for biological 
control of charcoal rot of melon (Macrophomina phaseolina) in laboratory and greenhouse conditions. J Crop Protec. 2014;3(4):509-521.

4. Lee Y, Chang H, Kim J, Kim J, Lee K. Lignocellulolytic mutants of Pleurotus ostreatus induced by gamma-ray radiation and their genetic similarities. Radiat Phys Chem. 2000;57:145-150. DOI: http://dx.doi.org/10.1016/s0969806x(99)00310-2

5. Shahbazi S, Ispareh k, Karimi M, Askari H, Ebrahimi MA. Gamma and UV radiation induced mutagenesis in Trichoderma reesei to enhance cellulases enzyme activity. Intl J Farm \& Alli Sci. 2014;3(5):543-554.

6. Zolan ME, Tremel CJ, Pukkila PJ. Production and characterization of radiation-sensitive meiotic mutants of Coprinus cinereus. Genetics 1988;120:379. PMC1203517

7. Hermosa MR, Grondona I, Iturriaga EA, Diaz-Minguez JM, Castro C, Monte E, Garcia-Acha I. Molecular characterization and identification of biocontrol isolates of Trichoderma spp. App Environ Microbiol. 2000;66:1890-1898. DOI: http://dx.doi.org/10.1128/aem.66.5.1890-1898.2000

8. Jiang X, Geng A, He N, Li Q. New isolate of Trichoderma viride strain for enhanced cellulolytic enzyme complex production. J Biosci Bioeng. 2011;111(2):121-127. DOI: http://dx.doi.org/10. 1016/j.jbiosc.2010.09.004

9. Li X, Yang H, Roy B, Park EY, Jiang L, Wang D. Enhanced cellulase production of the Trichoderma viride mutated by microwave and ultraviolet. Microbiol Res. 2010; 165(3):190198. DOI: http://dx.doi.org/10.1016/j.micres.2009.04.001.

10. Shahbazi S, Ahari Mostafavi H, Ebrahimi MA, Askari H, Mirmajlesi M, Karimi M. Enhancement of chitinase gene activity in mutated Trichoderma harzianum via Gamma radiation. Crop Biotechnol. 2013;5:33-40.

11. Zaldivar M, Velasquez JC, Contreras I, Perez LM. Trichoderma aureoviride a mutant with enhanced production of lytic enzymes: its potential use in waste cellulose degradation and/or biocontrol. Electron J Biotechnol. 2001;4(3):7-121. DOI: http://dx.doi.org/10.2225/vol4-issue3-fulltext-7

12. Abbasi PA, Miller SA, Meulia T, Hoitink HAJ, Kim JM. Precise detection and tracing of Trichoderma hamatum 382 in compost-amended potting mixes by using molecular markers. Appl Environ Microbiol. 1999;65:5421-5426. PMC91738

13. Cordier C Edel, Hermann V Martin, Laurent F, Blal B, Steinberg C, Alabouvette C. SCAR-based real time PCR to identify a biocontrol strain (T1) of Trichoderma atroviride and study its population dynamics in soils. J Microbiol Meth. 2007;68:60-68. DOI: http://dx.doi.org/10.1016/j.miment. 2006.06.006.

14. Savazzini F, Longa CM, Pertot I, Gessler C. Real-time PCR for detection and quantification of the biocontrol agent Trichoderma atroviride strain SC1 in soil. J Microbiol Meth. 2008;73:185-194. DOI: http://dx.doi.org/10.1016/j.mimet. 2008.02.004

15. Versalovic J, Koeuth T, Lupski R. Distribution of repetitive DNA sequences in eubacteria and application to finerprinting of bacterial genomes. Nucl Acids Res. 1991;19(24):68236831. DOI: http://dx.doi.org/10.1093/nar/19.246823

16. Edel V, C Steinberg, I Avelange, Laguerre, G. Comparison of three molecular methods for the characterization of Fusarium oxysporum strains. Phytopthology 1995;85(5):579-585. DOI: http://dx.doi.org/10.1094/phyto-85-579

17. Arora D, P Hirsch, Kerry BR. PCR-based molecular discrimination of Verticillium chlamydosporium isolates. Mycol Res. 1996;100(7):801-809. DOI: dx.doi.org/10.1016/S0953-7562(96) 80025-6

18. Jedryczka M, Rouxel T, Balesdent MH. Rep-PCR based genomic fingerprinting of isolates of Leptosphaeria maculans from Poland. Europ J Plant Pathol. 1999;105(8):813-823. DOI: http://dx.doi.org/10.1023/a:1008713907780

19. Purkayastha S, Kaur B, Dilbaghi N. Characterization of Macrophomina phaseolina, the charcoal rot pathogen of cluster bean, using conventional techniques and PCR-based molecular markers. Plant Patholol. 2006;55(1):106-116. DOI: http://dx.doi.org/10.1111/j.1365-3059.2005.01317.x

20. Aye S, Matsumoto M. Genetic characterization by rep-PCR of myanmar isolates of Rhizoctonia spp., causal agents of rice sheath diseases. J Plant Pathol. 2010;92(1):255-260.

21. Toda T, Hyakumachi M, Arora DK. Genetic relatedness among and within different Rhizoctonia solani anastomosis groups as assessed by RAPD, ERIC and REP-PCR. Microbiol Res. 1999;154(3):247-258. DOI: http://dx.doi.org/10.1016/s09445013(99)80022-6

22. Mc Donald J, Wong E, Godeas A. Differentiation of Tilletia species by rep-PCR genomic fingerprinting. Plant Dis. 2000;84(10):1121-1125. DOI: http://dx.doi.org/10.1094/pdis. 2000.84.10.1121

23. Ahari Mostafavi H, Safaie N, Fathollahi H, Babaie MHR Dorri, Lak MR. Pathological and molecular identification of Fusarium solani f. sp phaseoli isolates and determination of suitable gamma ray dose rate for mutation induction. $J$ Nucl Sci Technol. 2010;51:48-51.

24. Moradi R, Shahbazi S, Ahari Mostafavi H, Ebrahimi MA, Askari H, Mirmajlesi M. Investigation of Gamma radiation effects on morphological and antagonistic characteristics of Trichoderma harzianum. Crop Biotechnol. 2013;4:109-117.

25. Elad Y, Chet I. Improved selective media for isolation of Trichoderma spp. or Fusarium spp. Phytoparasitology 1983;11:55-58. DOI: http://dx.doi.org/10.1007/bf02980712

26. Rifai MA. A revision of the genus Trichoderma. Mycol Pap. 1969;116:1-56. DOI: 10.1007/BF02980712

27. Dennis C, Webster J. Antagonistic properties of species groups of Trichoderma111.Hyphal interactions. Trans Brit Mycol Soc. 1971b;57:363-369. DOI: http://dx.doi.org/10.1016/ S0007-1536(71)80050-5

28. Dennis C, Webster J. Antagonistic properties of species groups of Trichoderma 1. Production of non-volatile antibiotics. Trans Brit Mycol Soc. 1971a;57:25-39. DOI: http://dx.doi. org/10.1016/S0007-1536(71)80077-3

29. Safaie N, Alizadeh A, Saidi A, Rahimian H, Adam G. Molecular characterization and genetic diversity among Iranian populations of Fusarium graminearum, the causal agent of wheat head blight. Iran J Plant Pathol. 2005;41:171189.

30. Spadaro D, Lodovica M. Improving the efficacy of biocontrol agents against soil borne pathogens. Crop Protec. 2005;24:601-613. DOI: http://dx.doi.org/10.1016/j.cropro.2004.11.003. 
31. Szekeres A, Kredics L, Antal Z, Kevei F, Manczinger L. Isolation and characterization of protease overproducing mutants of Trichoderma harzianum. FEMS Microbiol Lett. 2004;233:215-222. DOI: http://dx.doi.org/10.1111/j.15746968.2004.tb09485.x

32. Vaidya R, Macmil S, Vyas PR. The novel method for isolating chitinolytic bacteria and its application in screening for hyperchitinase producing mutant of Alcaligenes xylosoxydans. Lett Appl Microbiol. 2003;36(3):129-134. DOI: http://dx.doi.org/ 10.1046/j.1472-765x. 2003.1274.x

33. Arisan-Atac I, Heidenreich E, Kubicek CP. Randomly amplified polymorphic DNA fingerprinting identifies subgroups of Trichoderma viride and other Trichoderma spp. capable of chestnut blight biocontrol. FEMS Microbiol Let. 1995;126:249-256. DOI: http://dx.doi.org/10.1111/j.15746968.1995.tb07426.x

34. Goes LB, Costa Freire ABL, Oliveira N. Randomly amplified polymorphic DNA of Trichoderma isolates and antagonism against Rhizoctonia Solani. Brazil Arch Biology Technol. 2002;45(2):151-160. DOI: http://dx.doi.org/10.1590/s151689132002000200005

35. Gomez I, Chet I, Herreraestrela A. Genetic diversity and vegetative compatibility among Trichoderma harzianum isolates. Mol Gen Genetics. 1997;256:127-135. DOI: http://dx.doi.org/ 10. $1007 / \mathrm{s} 004380050554$.

36. Schlick A, Kuhls K, Meyer W, Lieckfeldt E, Börner T, Messner $\mathrm{K}$. Fingerprinting reveals gamma-ray induced mutations in fungal DNA: implications for identification of patent strains of Trichoderma harzianum. Curr Gene. 1994;26(1):74-78. DOI: http://dx.doi.org/10.1007/ bf00326307

37. Zimand G, Valinsky L, Elad Y, Chet I, Manulis S. Use of the RAPD procedure for the identification of Trichoderma strains. Mycological Res. 1994;98(5)531-534. DOI: http://dx.doi.org/10.1016/s0953-7562(09)80474-7

38. Dodd SL, Hill RA, Stewart A. A duplex-PCR bioassay to detect a Trichoderma virens biocontrol isolate in non-sterile soil. Soil Biol Biochem. 2004;36:1955-1965. DOI: http://dx.doi.org/10.1016/ j.soilbio.2004.03.012

39. Trombert A, Irazoqui H, Martín C, Zalazar F. Evaluation of UV-C induced changes in Escherichia coli DNA using repetitive extragenic palindromic-polymerase chain reaction (REP-PCR). J Photochem Photobiol B Biol. 2007;89(1):4449. DOI: http://dx.doi.org/10.1016/j.jphotobiol.2007.08.003

40. Afsharmanesh H, Ahmadzadeh M, Majdabadi A, Motamedi F, Behboudi K, Javan-Nikkhah M. Enhancement of biosurfactants and biofilm production after gamma irradiation-induced mutagenesis of Bacillus subtilis UTB1, a biocontrol agent of Aspergillus flavus. Arch Phytopathol Plant Protec. 2013;46(15):1874-1884. DOI: http://dx.doi.org/10.1080/ 03235408.2013 .780374

41. Haggag WM, Mohamed HAA. Enhanecment of antifungal metabolite production from gamma-ray induced mutants of some Trichoderma species for control onion white disease. Plant Pathol Bull. 2002;11:45-56.

42. Mohamed HA, Haggag WM. Biocontrol potential of salinity tolerant mutants of Trichoderma harzianum against Fusarium oxysporum. Brazil J Microbiol. 2006;37(2):46-57. DOI: http://dx.doi.org/10.1590/s1517-83822006000200016. 